\title{
Underemployed Elizabethans: Gabriel Harvey and Thomas Nashe in the Parnassus Plays
}

The Parnassus comedies appeared at Cambridge University between 1598 and 1601. Since they make multiple allusions to topical events, texts, and personalities, scholars have conventionally read them as personal satire, with characters representing luminaries such as the recent Cambridge graduate Thomas Nashe. This article, however, demonstrates that speeches given to several characters in the last two plays are previously untraced quotations from another Cambridge alumnus, Nashe's antagonist Gabriel Harvey. While the plays evoke Harvey and Nashe, they do this because the two men's post-Cambridge experiences illustrate the plays' theme: the struggles of the scholar in the late-Elizabethan world.

\section{Uses of Literacy?}

In 2013, the American website Salon ran an article bitterly entitled 'Thanks for Nothing, College!' The author, Tim Donovan, assesses the economic value of a university education in light of rising tuition fees and consequent levels of student debt. He notes that, while the number of eighteen-to-twenty-four-year-olds enrolled as undergraduates had risen steadily since 1967, 'the aggregate demand for jobs requiring "cognitive tasks" (the type of work that traditionally necessitates a college degree)' had decreased with equal steadiness since the millennium. This had created a huge number of graduates in poorly paid clerical, retail, or service jobs, struggling to repay the cost of an education that had paid limited dividends - who were 'underemployed', in the sense of having a degree but not a commensurate job. Donovan concludes with a rhetorical question about university enrolment: 'Millennials need to ask themselves: Is it worth it?' ${ }^{2}$ The article's statistics are entirely American, and its conclusion deals with Americans who had

P.B. Roberts (peterbrynmorroberts@hotmail.com) completed his doctoral thesis, an edition of Gabriel Harvey's anti-Nashe tracts, at Cardiff University. 
become adults in the twenty-first century. ${ }^{2}$ The phenomenon may be less specific, however. In this article, I will examine some texts written over four centuries earlier, and on another continent, but whose authors and original audience might have found the scenario that Donovan's article describes hauntingly familiar. ${ }^{3}$

\section{The Parnassus Plays: Critical Tradition}

The three Parnassus plays appeared at Cambridge between 1598 and 1601, staged by students for students. We can be fairly sure of the dates, thanks to the large number of topical references in the plays. ${ }^{4}$ The first, The Pilgrimage to Parnassus, deals with university life. In the two-part The Return from Parnassus (I will call these plays The First Part and The Second Part for convenience), Studioso and Philomusus, the 'pilgrim' protagonists of the first play, venture out into the wider world in search of advancement. ${ }^{5}$ Their post-graduate sufferings in various trades provide opportunities for attacks on contemporary abuses. If we are to believe the prologue to the last of the trilogy, performances were convivial and rowdy affairs: the plays 'purchas'd [many] a Sophister a knocke with a clubbe, hindred the buttlers box, and emptied the Colledge barrells' (Second Part, line 41). ${ }^{6}$ The Second Part was printed in 1606 as The Retvrne from Pernassus: or The Scourge of Simony; the two other plays remained unprinted until W.D. Macray's edition of $1886 .^{7}$

The three plays differ greatly in length, style, and subject-matter. The brief Pilgrimage is allegorical, whereas the two longer Return plays are detailed and realistic. While the Pilgrimage contains satire on the various undergraduate 'types' that the two heroes encounter on their journey towards wisdom (drunkards, Puritans, addicts of Petrarchan love poetry), moreover, it ultimately affirms the value of learning. At its climax, having reached their destination (the mountain sacred to the Muses), the pair are glowing with pride, as if in hypothetical graduation robes:

Nere let the pilgrims to this laurel mounte

Fainte or retire in this their pilgrimage

Nowe let us boldlie rushe amonge theese trees

And heare the Muses tunefull harmonie.

Its two sequels, however, showcase a much more bitter vision - of the world to be expected outside academia.

In addition to their vitality as satire, the plays have a gossipy, allusive quality, as the youthful authors seek to impress their equally youthful auditors with their knowledge of both the Cambridge and the London scenes; Jonathan Bate 
describes the plays as having 'anecdotal value'. ${ }^{8}$ For instance, the character Gullio, a young gentleman who fancies himself a lover of poetry, exclaims, 'O sweet $\mathrm{M}^{\mathrm{r}}$ Shakspeare, Ile haue his picture in my study at the courte' (First Part, 3.1.1032), and James Shapiro comments, 'For these Cambridge undergraduates, Shakespeare was a living, breathing presence ... a copy of whose portrait they could imagine displaying in their rooms.' Perhaps the most-discussed scene in the plays comes in The Second Part, where Studioso and Philomusus audition for Shakespeare's company, the Lord Chamberlain's Men: Will Kemp mentions Shakespeare giving Ben Jonson a 'purge' (4.3.1772), and the exact nature of this has been the subject of much controversy. ${ }^{10}$ The Victorian scholar F.G. Fleay describes The Second Part as 'one continuous personal satire', confidently identifying six characters with contemporary writers. ${ }^{11}$ Perhaps because Fleay was one of the first scholars to write about the plays, in 1886, just as Macray's edition appeared, or because the plays were originally written for a select audience with a corresponding frame of reference, or because we have not fully shaken off nineteenth-century habits, personal satire has remained the dominant approach to the plays. ${ }^{12}$ I will argue that they have more than merely anecdotal value for scholars, as they ask their original audience disconcerting questions similar to Tim Donovan's about the value of education.

That the plays show knowledge of Gabriel Harvey and Thomas Nashe should not come as a surprise. Both men were highly combative figures from Cambridge's recent history. Harvey's fellowship at Trinity Hall had lapsed in 1591/2, but around 1588 he appears to have moved to London, first for an abortive legal career, and then to work as a reader for the printer John Wolfe, who between 1592 and 1593 published his writings against Nashe, a graduate of St John's College. ${ }^{13}$ Since departing from the university in 1588, Nashe had become a bestselling author of satire. He boasted that his signature tract, Pierce Penilesse his Supplication to the Diuell (1592), was 'most saleable, (passing at the least through ... sixe Impressions)'. It also began a bitter quarrel with Harvey by attacking his brothers Richard and John; Nashe's side of this feud continued until $1596 .{ }^{14}$ Their contention was still a live issue in the late 1590s: as part of their crackdown on satires, the archbishop of Canterbury and bishop of London decreed in 1599 'That all nasshes bookes and D[octor] Harvyes bookes be taken wheresoever they maye be found and that none of theire bookes bee ever printed hereafter. ${ }^{15}$ Many lines from the second and third Parnassus plays are in fact unidentified quotations from Harvey's anti-Nashe tracts, as I will demonstrate in the next section. This, I will conclude, requires that we historicize the plays in a less limited way than 
Fleay and his successors have done: not scanning them for encrypted Elizabethan celebrities but relating them to the bigger social picture.

\section{Echoes of Harvey}

It has become an article of faith with commentators on the plays that Ingenioso, who appears in all three, is a caricature of Nashe. Nashe's biographer Charles Nicholl declares, 'Ingenioso is clearly intended as a portrait of ... Nashe', calling the character 'Nashe as viewed by a young Elizabethan intellectual who deeply admired him and may perhaps have met him'. Paula Glatzer, author of the only monograph on the plays, likewise describes Ingenioso as 'modeled on Nashe', although simultaneously she concedes that he is also 'the disappointed scholar, one of the major types of Elizabethan satirist'. J.B. Leishman, editor of the plays' standard edition, states that 'much that we hear of and from Ingenioso corresponds very closely with the known facts of Nashe's life'. Even the most sophisticated reading of the plays, by Laurie Ellinghausen, focuses on what Nashe, as inspiration for Ingenioso, represented to his Cambridge contemporaries. ${ }^{16}$ Certainly, as a needy former Cambridge man who relocates to the London print industry to make a living by his pen and inveighs bitterly against stingy patrons, Ingenioso bears a resemblance to Nashe; he also quotes from Nashe's works in several places. ${ }^{17}$ The plays' characters, however, do not pair off neatly with contemporary literary personalities: in several places, in fact, Ingenioso channels Harvey.

In The First Part, Ingenioso attempts to woo a potential patron with a dedicatory epistle beginning, 'Desolat eloquence $\&$ forlorne poetrie, youre moste humble suppliant[s] in forma pauperum, laye prostrate at youre daintie feet, and adore youre excellencie' (1.1.300). This is a very close quotation, but not from Nashe: instead it comes from the longest and most bitter of Harvey's writings against him, Pierces Supererogation (1593). Harvey says, addressing Nashe ironically, 'Desolate Eloquence, and forlorne Poetry, thy most-humble Suppliants in forma pauperum, ... lye prostrate at thy dainty foote, and adore the Idoll-excellency of thy monstrous Singularity'. ${ }^{18}$ As will often prove to be the case, the play transforms Harvey's original, adding a layer of meaning for viewers who are aware of the quote and removing one for viewers who are not.

This is not the only time the play's alleged Nashe surrogate uses the words of Nashe's enemy. Later in this scene, Ingenioso, asked by Philomusus how his suit has fared, replies, 'Slender relife I can assure youe in the predicament of priuation' (1.1.352). This rejoinder quotes from Harvey's first salvo in the paper war, Fovre Letters, and Certaine Sonnets (1592), for much of which his target is not Nashe but 
Robert Greene. Having described Greene's lonely and impoverished death, Harvey comments, 'God helpe good fellowes, when they cannot helpe themselues. Slender reliefe in the predicamente of priuations. ${ }^{19}$ Like Nashe and Harvey, Greene was a Cambridge graduate who, trying to subsist among the hacks that swarmed around Paul's Churchyard, fell on evil days: fond of advertising his two master's degrees on the title-pages of his books, as per Harvey's account in Fovre Letters he appears to have died in penury. ${ }^{20}$ Ingenioso's quoting not from Nashe but from Harvey's description of Greene raises the possibility that Ingenioso represents not an individual but a community that all three men belonged to - a point that I will return to later.

Only a few lines further into the same scene, Ingenioso describes the same patron listening to him 'with a Camelions gape, an[d] a verie emphaticall nodd of the heade' (1.1.362). Once more, this phrase does not come from Nashe; instead it appears in Harvey's description of a pointed exchange between himself and Andrew Perne, the erstwhile vice-chancellor: after Harvey twitted Perne, 'He smiled, and replyed after his manner, with a Chameleons gape, and a very emphaticall nodd of the head' (Pierces Supererogation, Ddr). ${ }^{21}$ Cambridge men would still have remembered Perne in the 1590s: he remained notorious for his apostasies in the turbulent middle years of the century, although conservative Protestants might have nursed fonder memories of him as a university administrator and benefactor. There may have been audience members who recognised Perne's mannerisms, and Harvey's attacks on him could have been an enduring scandal. ${ }^{22}$ The words that Ingenioso cites, however, have no relevance to Nashe.

To complicate the picture, Ingenioso is not the only character who quotes Harvey's writings. Luxurio, a ballad writer, also features in The First Part. Heading for London in hope of a good sale, he prays that 'what ere I make will beare marmelett and sukket in the mouthe' (1.1.407). This unusual phrase splices the proverbial 'to bear meat in the mouth', meaning to be a source of profit (financial or moral), with marmalade and succade (fruit preserved in sugar), a combination mentioned by early modern authors as the epitome of the delicacy. It comes from A New Letter of Notable Contents (1593), the last of Harvey's anti-Nashe tracts. Much of this book consists of praise of an unnamed female patron of Harvey's who is going to write against Nashe, and Harvey at one point says of this 'Gentlewoman's' writings, 'euery Periode of her stile carrieth marmalad and sucket in the mouth'. ${ }^{23}$ Once again, the context is different from the original, as Harvey seems to mean moral or aesthetic, not material, enhancement.

The First Part also features Gullio, the Shakespeare-loving fop who employs Ingenioso as a ghost writer. Gullio, who believes himself 'a complet gentleman' 
(3.1.928), has little in common with Harvey, the pugnacious son of a ropemaker from rural Essex. ${ }^{24}$ But, like Ingenioso and Luxurio, he also quotes from Harvey's works. When Gullio claims to have written to his mistress 'Mercuriall and Martiall discourses, in the actiue and chiualrous vaunt' (5.1.1367), the play parodies Pierces Supererogation, where Harvey praises the works of Philip Sidney, James VI, and others as 'Mercuriall, and Martiall Discourses, in the actiue, and chiualrous veine' (H2v). In the very next sentence, Gullio describes himself under his mistress's window, 'playinge vpon my Iuorie lute moste enchantinglie' (5.1.1370). In Pierces Supererogation, Harvey ironically compares Nashe's 'Orient witt' to 'the renowned achates of king Pyrrhus, that is, the tabernacle or chauncell of the Muses, Apollo sitting in the midst, and playing vpon his Iuory harpe most enchauntingly' (Aa2v). ${ }^{25}$ Shortly afterwards, Gullio announces that if he meets his romantic rival, 'I woulde make him not refuse the humblest vassalage to the soale of my bootes' (5.1.1380). This phrase also is taken from Pierces Supererogation, where Harvey promises that, if Nashe can do anything to confirm his selfimage as 'the valiantest and brauest Actour, that euer managed penne', then he will 'refuse not the humblest vassalage to the sole of his boote' (S4r). Finally, enraged by a message that Ingenioso brings, Gullio says that he would fight him 'Were it not that I will not file my handes vpon suche a contemptible rascalde' (5.1.1426). This outburst, too, echoes Pierces Supererogation, in which Harvey says that friends have entreated him 'in sober earnest, not to foile my hands vpon such a contemptible rascall' as Nashe (T4r). ${ }^{26}$

One of the most ostensibly contemporary moments in the plays happens in The Second Part, when Ingenioso and his friend Iudicio leaf through the recent anthology Bel-vedere, or The Garden of the Muses (1600), commenting on each of the authors represented. John Marston appears on the list: at this point he was a published satirical poet just beginning his career as a playwright. ${ }^{27}$ Ingenioso says that Marston

Cutts, thrusts, and foines at whomesoeuer he meets,

And strewes about Ram-ally meditations.

Tut, what cares he for modest close coucht termes,

Cleanly to gird our looser libertines?

Giue him plaine naked words stript from their shirts ...

This passage conveys both the violence of Marston's satire and its sexual explicitness. Ram Alley, off London's Fleet Street, was a rough area frequented by prostitutes. In the 1611 city comedy of the same name, one character declares that 'Ram-Alley stinks of cooks and ale'; 'Ram-ally meditations' are presumably the 
kind of invective the whore Francis utilizes later in the play when abusing her pimp. ${ }^{28}$ However appropriate the phrase is to Marston, though, it is of an older vintage than his literary career. It appears in Pierces Supererogation, although it is not Harvey's; his friend John Thorius, who contributes verses to the book, uses it to describe Nashe's crudely aggressive satire:

And now so neatly hath thy railing merit

(I should haue said Ramme-ally meditations)

Procur'd applause vnto thy Clarret spirit,

And sack-sopt miseries of thy Confutations.

That now each Iuy-bush weepes her Teares in ale ...

$(\mathrm{Gg} 2 \mathrm{v}){ }^{29}$

Iudicio responds to Ingenioso with a similar verdict of his own on the combative Marston:

I, there is one that backes a paper steed

And manageth a pen-knife gallantly,

Strikes his poinado at a buttons breadth,

Brings the great battering ram of tearms to towne ...

As Leishman notes, the last line quotes a passage in Pierces Supererogation where Harvey pretends to quake with fear at Nashe's threats: 'When the iron Cart is made, and the fierie horses foled, they shall bring the mightie Battring-ram of termes, and the great Ordinance of miracles, to towne: aske not then, how he will plague me' (T1r). In the second line, however, there is another echo of Harvey, from exactly the same page of Pierces Supererogation: 'never fauchon better managed, then some tidy penneknifes'. ${ }^{30}$ Since both interlocutors are quoting Harvey's words, these echoes cannot be evidence of personal satire.

Ultimate proof that Ingenioso is not simply a portrait of Nashe occurs towards the end of this scene, when Ingenioso comes across Nashe's name on the list and elegizes him (Nashe had died by 1601): 'I, heer's a fellow, Iudicio, that carryed the deadly Stockado in his pen, whose muse was armed with a gagtooth' (1.2.311). ${ }^{31}$ Leishman notes in the latter phrase an echo of Pierces Supererogation, where Harvey says of Nashe, 'Take heede of the man, whom Nature hath marked with a gag-tooth' (S4v); verses appended to Pierces Supererogation likewise call Nashe a 'gagtooth'd fopp' (***1r), and Charles Nicholl concludes that individual wayward teeth projecting at angles' were one of Nashe's distinguishing characteristics. ${ }^{32}$ The fencing language (a stoccado is a kind of stab) also echoes Pierces Supererogation, where Harvey says that John Lyly, another one of his manifold enemies, 'carriest the dubble stoccado in thy penne' (K1v). In effect, then, at this 
moment Ingenioso not only pronounces sentence on the dead Nashe; as when he quotes Harvey on Greene's death, or on Andrew Perne, he uses words of Gabriel Harvey's applied to a different person altogether. So, however it has silted into orthodoxy that Ingenioso is a depiction of Nashe, to do justice to these plays we need to move beyond the roman à clef model that the Victorians established.

\section{Underemployed Elizabethans}

We can infer several things from the echoes of Harvey that the Parnassus plays give to these various characters. The most obvious conclusion is that, as his biographer Virginia F. Stern puts it, Cambridge 'had not forgotten Harvey and his colourful eccentricities', even though five years had passed between the last of his publications (A New Letter) and the earliest of these plays. ${ }^{33}$ Cambridge would have had scant reason to forget Harvey. In 1573, several fellows of Pembroke Hall had attempted to block the granting of his MA, citing his intellectual unorthodoxy ('a main defender of straung opinions') and lack of interpersonal skills ('great and intolerable arroganci'). This, Harvey complained, resulted in his 'great defamation in the town'. ${ }^{34}$ His feud, not only with Nashe and others of the 'University Wits', but also with Andrew Perne, had entered the public arena of print. ${ }^{35}$ Perne blocked Harvey's bids to become public orator in 1580 and master of Trinity Hall in 1585. In his correspondence with Edmund Spenser, printed as Three Proper, and Wittie, Familiar Letters (1580), Harvey had vented his frustration in a bitter attack on the older man. Unfortunately, this outburst had appeared as part of a larger diatribe against affairs at Cambridge in general, and Harvey was forced to write 'a large Apology of my duetiful, and entier affection to that flourishing Vniuersitie' to placate the authorities. ${ }^{36}$ All in all, the impression made on the university by Harvey's storm-wracked career must have been considerable.

In the Parnassus plays, though, the context of these quotations from Harvey is often completely different from that of the original. Several of them are put in the mouth of Ingenioso, described by Fleay as 'too clearly Thomas Nash to need further comment'. ${ }^{37}$ Several are spoken by the affluent Gullio, who bears very little resemblance to Harvey, either the real man or the figure from Nashe's caricature. Nashe repeatedly represents Harvey as a man living in penury: 'his discontented pouertie (more disquiet than the Irish seas) hath driu'n him from one profession to another'. Bitter comments in Harvey's marginalia on the status of the learned man without money seem to suggest that this representation had a factual basis. ${ }^{38}$ Gullio clearly sees himself as a lover in the Petrarchan mould, moreover, whereas Harvey in Pierces Supererogation is scathing about the cult of courtly love: 'Some 
feruent, and many counterfait loouers, adore their mistresses; and commit Idolatrie to the least of their bewties' (N1r). His own sonnets in Fovre Letters deal entirely with public virtues and the active life.

The way the plays disperse these quotations throughout, regardless of characters, has consequences for applying the concept of personal satire to the texts. In the first place, specifically, it has consequences for the ballad monger Luxurio, long regarded as representing Harvey. Wilhelm Lühr, one of the first scholars to give the plays close attention, made the identification in 1900; in 1952, Willem Schrickx claimed to have found supplementary evidence for Lühr's theory. Virginia F. Stern's sole mention of the plays in her biography of Harvey is concerned entirely with Luxurio as a caricature of him. Leishman entertains the possibility, noting that, in the badinage in their one scene together, Luxurio 'mocks at Ingenioso's poverty just as Harvey had mocked at Nashe's. ${ }^{39}$ Luxurio's resemblance to Harvey is as limited as Gullio's, though. He seems to be a relative of Shakespeare's Bardolph: the text repeatedly emphasizes the redness of his face. ${ }^{40}$ There is nothing in Nashe's (quite detailed) descriptions of Harvey to suggest that this ruddiness was one of his characteristics. ${ }^{41}$ Lest there be any doubt as to the cause of Luxurio's roseate hue, the text also emphasizes his fondness for the hard stuff. Harvey, by contrast, seems to have believed in 'near-abstention from drinking'; his avoidance of convivial social gatherings was already notorious when he was a junior academic. ${ }^{42}$ Luxurio's other salient feature is his writing of ballads, and in his publications, Harvey displays the kind of contempt for ballad literature typical for a university-educated author of the period. ${ }^{43}$ If Luxurio's profession (and his rosacea) identified him with any particular late-Elizabethan personality, it would be the balladeer William Elderton, but it seems to have been conventional to describe ballad writers as drunken and red-faced, so the detail of Luxurio's face does not indicate that he satirizes any individual at all. ${ }^{44}$

Like other contemporary scholars seeking personal satire in late-Elizabethan texts, Lühr draws up a table making characters in the plays cryptograms for personalities of the era. ${ }^{45}$ Clearly the plays use these echoes of Harvey, Nashe, and others for a purpose, but I want to argue that they evoke the authors in a less neatly schematic way. Not only does Ingenioso cite Nashe (and Harvey), but Studioso compares him to Robert Greene. At the start of The First Part, when the plays' two protagonists run into the starving hack again, Studioso begs to see a work in progress: 'if thou haste ere an Omne tulit punctum, ere a Magister artium vtriusque Academia, ... ere a needie Pamphlet, drincke of a sentence to vs' (1.1.209-11). Harvey says witheringly of Greene, 'Omne tulit punctum, qui miscuit vtile dulci ... forsooth was his professed Poesie', and Leishman points out that 
Greene habitually used the Horatian tag on the title-pages of his books, where he likewise advertised his two master's degrees. ${ }^{46}$ Luxurio, as well as echoing Harvey, also parodies John Lyly. In The First Part, Luxurio enters saying to his page:

There is a beaste in India calld a Polecatt, that the further shee is from youe the less she stinks, and the further she is from you, the less you smell her: this dry cuntrie is that Polecatt, that creates suche an vnsauorie smell in the noistrells of a liquid scholler ... (5.2.1475)

As Leishman says, this absurd speech is a parody of Lyly's prose style, and not only was the author of Euphues Harvey's avowed enemy, but Harvey was publicly scathing about his elaborate similes, coining the word 'Euphuisme' in contempt. ${ }^{47}$ Just as Ingenioso cannot personally represent Harvey, Nashe, and Greene, Luxurio cannot be Harvey, Lyly, and a ballad writer. Both characters, it seems to me, are composite figures epitomizing that Elizabethan novelty, the university-educated professional author. A useful analogy for the impressionistic way the plays conjure up images of Nashe, Harvey, and others might be with Poetaster, where Jonson, eminently capable of translating Ovid from the original, chooses in one place to have Ovid quote himself in Marlowe's translation, apparently to suggest a connection between the Roman and a brilliant but morally problematic poet of Jonson's own day. ${ }^{48}$ The Ovid of Poetaster is not simply an encoded Marlowe, but Marlowe and Ovid, Jonson seems to be saying, belong to the same category, just as the Parnassus plays make Ingenioso, Luxurio, Nashe, and Harvey denizens of the same class.

The role Gabriel Harvey fulfils is the same as Nashe's: both illustrate the plays' main theme, by virtue of their personal plights. The prologue to The Second Part describes this theme as 'a schollers discontent' (line 69). During the sixteenth century, the number of Englishmen enrolling at each university boomed, as Oxford and Cambridge responded to the Elizabethan church's need for educated clergy, as both the aristocracy and the newly prosperous 'middling sort' became convinced of the benefits of sending their sons to university, and as the Reformation meant that schools, scholarships, and colleges took the places vacated by chapels and chantries as objects of endowment. ${ }^{49}$ Sixteenth-century humanist ideology also played a part, as the university shifted from being a place to retreat from the world (on the medieval monastic model) to a place equipping students to engage with it, preferably at a governmental level. In 1564, the queen herself had expressed this ethos when she declared, in a speech at Cambridge, 'there will be no directer, no fitter course, either to make your fortunes, or to procure the favor 
of your prince, than, as you have begun, to ply your studies diligently'.50 In the late-Elizabethan market for graduates, however, supply appears to have exceeded demand. Many of these surplus learned ended up in poorly paid employment, but others may have been even less fortunate: the 1598 'Act for punishment of rogues, vagabonds and sturdy beggars' indicts 'all persons calling themselves scholars going about begging. ${ }^{51}$ Various commentators have seen this social phenomenon as a factor contributing to the 'satire boom' of the 1590s; Nashe's Pierce Penilesse begins his complaint about contemporary evils by stating that he has 'spent many yeeres in studying ... and liu'de a long time without mony'. ${ }^{52}$

The Return from Parnassus dramatizes this situation, from and for a Cambridge perspective. ${ }^{53}$ Ingenioso in The Pilgrimage warns Studioso and Philomusus: 'take heede I take youe not napping twentie yeares henc in a viccars seate ... or els interpretinge Pueriles Confabulationes to a companie of seauen yeare olde apes' (5.651-4). As Ingenioso's words suggest, teaching children appears to have been a particularly poorly remunerated and regarded activity (not yet accorded the status of a profession), with the disgruntled graduates who treated it as a stop-gap dependent on gifts to supplement their income. ${ }^{54}$ Studioso does indeed become a tutor in The First Part, suffering at the hands of an obnoxious citizen family, but Philomusus is even less lucky, landing the job of sexton: although he is tasked with whipping dogs, sweeping the church, and burying the dead, the greatest indignity is the pity of the rustic churchwarden who ultimately fires him, kindly making him out a passport to stop him being apprehended as a vagrant. Because of its Shakespeare connections, the scene with Will Kemp and Richard Burbage has received disproportionate attention, but these are just two in a parade of comical unlettered characters, speaking malapropisms and with a ludicrous sense of their own importance, that the impecunious scholars have to kowtow to. After the players have exited, Philomusus exclaims bitterly, 'And must the basest trade yeeld vs reliefe?' (4.3.1846). Whatever its implications for Shakespeare and Jonson, in context the effect of this scene is to illustrate the dire straits the plays' heroes have been reduced to, auditioning for these two idiots.

Seeing the plays too much in terms of personal satire runs the risk of making their relevance seem specific, and not general, as the plays themselves invite the audience to see it. For instance, when Consiliodorus, the paternal figure who packs the two protagonists off to university at the start of The Pilgrimage, learns about the fate of Studioso and Philomusus, his lament extracts a general moral:

Hencforthe let none be sent by carefull syres,

Nor sonns nor kinred, to Parnassus hill, 
Since waywarde fortune thus rewardes our coste

With discontent, theire paines with pouertie. (First Part 3.1.1066)

The plays invoke several Cambridge-educated authors as evidence of the neglect of learning - not only Harvey, Nashe, and Greene but no less a figure than Edmund Spenser. When Iudicio discusses Spenser's life and work in the Belvedere scene in Second Part, he not only describes him as the apex of Elizabethan cultural achievement; he has in mind the rumours circulating about his impoverished death: 55

And yet for all, this vnregarding soile

Vnlac't the line of his desired life,

Denying mayntenance for his deare releife:

Carelesse ere to preuent his exequy,

Scarce deigning to shut vp his dying eye.

Ingenioso's reply makes Spenser an exemplum: 'Pity it is that gentler witts should breed, / Where thick-skin chuffes laugh at a schollers neede' (1.2.220-6). Other speeches bring the message even closer to home. Both Return plays end metatheatrically, with the students onstage acknowledging the relevance of the plight of the students depicted to the students in the audience. Echoing the plays of Plautus and Terence, that typically end with actors calling for a round of applause ('Plaudite'), 56 The First Part has all the characters onstage agreeing that the play's bitter conclusion reflects contempt for learning in the wider world, and asking all the discontented scholars watching to 'giue vs a Plaudite' (5.3.1571). The Second Part similarly ends with an appeal to the 'refined sprights' in the audience, who can sympathize with 'poore schollers miseries', to 'giue vs a Plaudite' (5.4.221323). In other words, the plays hold out a warning (what the Elizabethans might have called a 'mirror') to their original audience about their prospects outside Cambridge.

From the start, scholarship on the Harvey-Nashe quarrel presented the two as polar opposites. In 1910, Nashe's editor R.B. McKerrow noted that the conventional view of it was as a clash 'between the brilliant young wit and the dull conceited pedant', and while McKerrow sought to revise this in Harvey's favour, he still emphasized polarity when he concluded, 'There must have been some inherent opposition between the two: each must have represented to the other the class or the type which he most detested'. Subsequent scholars have followed his lead, contrasting Nashe and Harvey in terms of their personalities, their attitudes to emergent notions of professional authorship or the material text, the satirical 
personae they chose, and their religious and factional affiliations, amongst other things. ${ }^{57}$ But it appears from the Parnassus plays that, to a Cambridge audience at least, they had common ground. Both Harvey and Nashe were Cambridge alumni struggling to survive in London's marketplace of print, trying to apply the verbal skills they had acquired, and both exemplified to the Parnassus plays' original audience the possible fate that awaited them in the world outside. In an economy where the education he had invested so much in was devalued, Gabriel Harvey came to the conclusion that since 'Common Lerning, \& $\mathrm{y}^{\mathrm{e}}$ name of A good schollar, was neuer so much contemn'd, $\&$ abiectid of princes ... it necessarily concernith, \& importith ye lernid ... to hate $y^{r}$ books'. Similarly, Nashe has Pierce Penilesse bitterly regret wasting time on acquiring scholarship that has proved useless:

Ah worthlesse Wit, to traine me to this woe,

Deceitfull Artes, that nourish Discontent:

Ill thriue the Follie that bewitcht me so;

Vaine thoughts adieu, for now I will repent. 58

All of which is an Elizabethan way of saying, 'Thanks for nothing, college'! 


\section{Notes}

I would like to thank Professor Catherine Belsey (Swansea University) and the anonymous reviewers of Early Theatre for all the help and encouragement they have given me with this article.

1 Tim Donovan, 'Thanks for Nothing, College!', Salon, 30 June 2013, http://www. salon.com/2013/06/30/thanks for nothing collegel. On 'underemployment', see Jordan Weissmann, 'The Growth of College Grads in Dead-End Jobs (in 2 Graphs)', The Atlantic, 16 January 2014, http://www.theatlantic.com/business/archive/2014/01/the-growth-of-college-grads-in-dead-end-jobs-in-2-graphs/283137/.

2 Across the Atlantic, though, similar developments occurred: see 'Over-Qualification and Skills Mismatch in the Graduate Labour Market', Chartered Institute of Personnel and Development, 18 August 2015, http://www.cipd.co.uk/knowledge/work/ skills/graduate-labour-market-report.

3 Obviously a parallel between the late-Elizabethan moment and our own cannot be exact; for example, the protagonists of the Parnassus plays seek not only jobs but patronage. For an epistle dedicatory of the kind Ingenioso addresses to a patron in The First Part of the Return from Parnassus 1.1, an author might receive widely varying sums, or perhaps nothing; depending on their status, they might, more intangibly, be seeking the prestige or opportunities that association with a particular patron might give them. For a suggestion of the various ways that literary patronage operated, see Edwin Haviland Miller, The Professional Writer in Elizabethan England: A Study of Nondramatic Literature (Cambridge, MA, 1959), 94-136; all references to the plays are to J.B. Leishman (ed.), The Parnassus Plays, 1598-1601 (London, 1949). Any comparison of patronage with the 'adjunct' system, whereby a teacher is given institutional affiliation but not subsistence, would be merely fanciful.

4 For a discussion of the plays' dates, see Leishman (ed.), Parnassus Plays, 24-6.

5 I use the titles used by Leishman, although Paula Glatzer argues that The Second Part should be called The Progress from Parnassus. See Glatzer, The Complaint of the Poet: The Parnassus Plays (Lewiston, NY, 1977), 335-6.

6 Rowdiness at Cambridge performances seems to have been conventional: see G.C. Moore Smith, College Plays Performed in the University of Cambridge (Cambridge, 1923), 45-6, https://doi.org/10.1017/CBO9780511707094.

7 Leishman (ed.), Parnassus Plays, 10.

8 Jonathan Bate, The Genius of Shakespeare (London, 2016), 22.

9 James Shapiro, Contested Will: Who Wrote Shakespeare? (London, 2010), 268-9. 
10 For some recent examples, see Grace Tiffany, “"That Reason Wonder May Diminish": As You Like It, Androgyny, and the Theater Wars', Huntington Library Quarterly 57 (1994), 213-39, https://doi.org/10.2307/3817601; Tom Cain (ed.), Poetaster (Manchester, 1995), 36-8; James P. Bednarz, Shakespeare and the Poets' War (New York, 2001), 32-52; Jonathan Bate, Soul of the Age: The Life, Mind and World of William Shakespeare (London, 2008), 375-81.

11 Frederick Gard Fleay, A Biographical Chronicle of the English Drama, 2 vols (London, 1891), 2.351-4. Fleay, A Chronicle History of the Life and Work of William Shakespeare, Player, Poet, and Playmaker (London, 1886), 45, had previously identified The Second Part's reference to Shakespeare's 'purge' of Jonson as an allusion to Troilus and Cressida.

12 Much of the scholarship following Leishman's 1949 edition has concentrated on either personal satire, or establishing the plays' authorship, or both: see Willem Schrickx, 'The Portraiture of Gabriel Harvey in the Parnassus Plays and John Marston', Neophilologus 36 (1952), 225-34, https://doi.org/10.1007/bf01515099; Marjorie L. Reyburn, 'New Facts and Theories About the Parnassus Plays', PMLA 74.4 (1959), 325-35, https://doi.org/10.2307/460442; Frank Livingstone Huntley, 'Joseph Hall, John Marston, and The Returne from Parnassus', Earl Miner (ed.), Illustrious Evidence: Approaches to English Literature of the Early Seventeenth Century (Berkeley, CA, 1975), 3-22; E.A.J. Honigmann, John Weever: A Biography of a Literary Associate of Shakespeare and Jonson, Together with a Photographic Facsimile of Weever's Epigrammes (1599) (Manchester, 1987), 51-6.

13 Virginia F. Stern, Gabriel Harvey: His Life, Marginalia and Library (Oxford, 1979), 80-4, 101-2. Often repeated as fact, the statement that Harvey worked for Wolfe as a proofreader has its basis in Nashe's hostile mock biography in Haue with You to Saffron-Walden. See The Works of Thomas Nashe, ed. R.B. McKerrow, rev. F.P. Wilson, 5 vols (Oxford, 1958), 3.87-9, 102; all further references to Nashe are to this edition. Nonetheless, Stern identifies the handwriting in a copy of Greene's Perimedes, printed by Wolfe, as Harvey's, marking up errors for a second edition (Gabriel Harvey, 101n). That Harvey might have worked for Wolfe in this capacity is not impossible: the scholars John Foxe, John Bale, and Laurence Humphrey all worked as 'correctors' after leaving Marian England for the theologically more congenial environment of Basel; see J.H. Mozley, John Foxe and His Book (London, 1940), 50-1. Certainly, Harvey's relationship with Wolfe was closer than that of most Elizabethan authors with their printers. One of the books Harvey owned and annotated was a present from Wolfe (Stern, Gabriel Harvey, 223); A New Letter of Notable Contents takes the form of an epistle to Wolfe and, as Clifford Chalmers Huffman puts it, Harvey's 
'tone is respectful and treats Wolfe as an intellectual and social equal' (Elizabethan Impressions: John Wolfe and His Press (New York, 1988), 115).

14 Nashe, Haue with You to Saffron-Walden, 3.35; Pierce Penilesse His Supplication to the Diuell, 1.195-9. On the date of his departure for London, see McKerrow's discussion in his appendix to the Works, 5.8-12.

15 Cited in Richard A. McCabe, 'Elizabethan Satire and the Bishops' Ban of 1599', Yearbook of English Studies 11 (1981), 188, https://doi.org/10.2307/3506267.

16 Charles Nicholl, A Cup of News: The Life of Thomas Nashe (London, 1984), 231-2; Glatzer, Complaint of the Poet, 59, 62; Leishman (ed.), Parnassus Plays, 72; Laurie Ellinghausen, Labor and Writing in Early Modern England, 1567-1667 (Aldershot, 2008), 37-62. Pace Leishman, Ingenioso resembles Nashe's public profile more closely than he does the man himself: see Philip Schwyzer, 'Summer Fruit and Autumn Leaves: Thomas Nashe in 1593', English Literary Renaissance 24 (1994), 584-7, https://doi.org/10.1111/j.1475-6757.1994.tb01499.x.

17 Leishman assembles a case for seeing Ingenioso as a caricature of Nashe (Parnassus Plays, 71-9). There is one quotation from Nashe that he did not spot, however. Ingenioso hopes that now his potential patron is ill, 'the diuell and his conscience betwixt them will let him bloude in the liberall vaine' (First Part, 1.1.226); Pierce Penilesse sets off in search of a patron declaring, 'I determined to clawe Auarice by the elbowe, ... and lette him bloud with my penne (if it might be) in the veyne of liberalitie' (Nashe, Pierce Penilesse, 1.161). Cf. also First Part, 5.1 .1421 and Nashe, Christs Teares over Iervsalem, 2.181.

18 Gabriel Harvey, Pierces Supererogation, or a New Prayse of the Old Asse (London, 1593; sтC: 12903), Z4v. All further references are to this edition.

19 Gabriel Harvey, Fovre Letters, and Certaine Sonnets, 2nd ed. (London, 1592; STC: 12900.5), B3r.

20 Harvey explicitly contrasts Greene's status and behaviour with what he expects of a man of his education: 'his fonde disguisinge of a Master of Arte with ruffianly haire, vnseemelye apparell, and more vnseemelye Company ... his beggarly departing in euery hostisses debt ... ' (Fovre Letters, B2r-v). Greene's lonely death in poverty is part of his personal mythos, hence Greenes, Groats-Worth of Witte, where the author refers to 'my want, the murderer of my wit', declares that 'a harlot ... bringeth a man to a morsell of bread and nakednes: of which my selfe am instance', describes himself as 'driuen ... to extreme shifts', etc. Greenes, Groats-Worth of Witte, Bought with a Million of Repentance (London, 1592; sтc: 12245), E3r, E4r, F1v.

21 The belief that the chameleon kept its mouth constantly wide open as it lived on air dates back to Pliny's Natural History, H. Rackham, W.H.S. Jones, and D.E. Eichholz 
(eds), 10 vols (London, Cambridge, MA, 1938-62), 3.87, https://doi.org/10.5962/ bhl.title.30319.

22 See Patrick Collinson, 'Perne the Turncoat: An Elizabethan Reputation', Elizabethan Essays (London, Rio Grande, OH, 1994), 179-217.

23 Gabriel Harvey, A New Letter of Notable Contents (London, 1593; sтc: 12902), C1v. In The Mirrour of Madnes (London, 1576; sTC: 17980, B2v), the Epicure ends his list of the gastronomic delights that he enjoys daily with 'Succettes, Marmalades, and greene ginger'; Thomas Walkington, in The Optick Glasse of Hvmors (London, 1607; sTC: 24967, E3r), writes that the 'Poet of yore' was held 'the A per se A of all Artistes; the Summa totalis of witte: the second dish, the marmalade and sucket of the Muses'. Apparently, this was holiday fare for Cambridge scholars: when men from Trinity College visited Queens' to stage seasonal entertainment on 8 January 1547/8, the college accounts record payment 'pro le sukket marmaled carawys cakes pro vino et pomis' laid on for the occasion (Moore Smith, College Plays, 19).

24 On the contrary, Harvey appears to have had the experiences that he did at Cambridge precisely because he was not a gentleman. See McKerrow's comments in Nashe's Works, 5.69-71; Stern, Gabriel Harvey, 17.

25 According to legend, Pyrrhus, king of Epirus, had a jewel on which an image of Apollo and the Muses had appeared naturally (Pliny, Natural History, 10.167).

26 Harvey's editors J.P. Collier and A.B. Grosart both read 'soile'. Collier, Pierces Supererogation, or a New Prayse of the Old Asse (London, 1870), 152; Grosart, The Works of Gabriel Harvey, D.C.L., 3 vols (London, Aylesbury, 1884-5), 2.233. Whether or not there is textual corruption here, the sense was clear enough to the author of The First Part. 'File' could mean 'defile' (Leishman, ed., Parnassus Plays, 203n).

27 Scholars disagree on exactly what Marston's first play was. See, for example, David G. O'Neill, 'The Commencement of Marston's Career as a Dramatist', Review of English Studies ns 22 (1971), 442-5; Roslyn Lander Knutson, Playing Companies and Commerce in Shakespeare's Time (Cambridge, 2001), 75-82, https://doi.org/10.1017/ CBO9780511486043.

28 Lording Barry, Ram Alley, ed. Peter Corbin and Douglas Sedge (Nottingham, 1981), 1.4.488, 2.1.525-36.

29 Punctuation is as per the original. For more contemporary references to the alley, see Edward H. Sugden, A Topographical Dictionary to the Works of Shakespeare and His Fellow Dramatists (Manchester, 1925), s.v. 'Ram Alley'.

30 Egerton Brydges' modern-spelling edition of Pierces Supererogation (London, 1815, 147), reads 'faulchion': a 'falchion' is a curved broadsword.

31 In the same year, Charles Fitzgeffrey published an elegy on Nashe in his Affania. For an English translation, see Nicholl, A Cup of News, 269. 
32 Ibid, 9.

33 Stern, Gabriel Harvey, 130. When Gullio recites Shakespeare, Leishman interprets the minor verbal variants as evidence that 'the author was quoting from memory' (Parnassus Plays, 184n): perhaps the same applies to the plays' quotations from Harvey.

34 Letter-Book of Gabriel Harvey, a.d. 1573-1580, ed. Edward John Long Scott (Westminster, 1884), 10, 18, 17, https://doi.org/10.1017/s2042170200007294.

35 John Lyly and Robert Greene both attacked Harvey and his family. See Lyly, Pap with an Hatchet, ed. Leah Scragg (Manchester, 2015), 59-60; Edwin Haviland Miller, 'Deletions in Robert Greene's A Quip for an Upstart Courtier (1592)', Huntington Library Quarterly 15 (1951-52), 277-82, https://doi.org/10.2307/3816357. Hale Moore reconstructs the apparent antipathy between Harvey and Christopher Marlowe; see 'Gabriel Harvey’s References to Marlowe', Studies in Philology 23 (1926), 337-57.

36 Stern, Gabriel Harvey, 53-4, 77-8; Harvey, Fovre Letters, C2v-C3r.

37 Fleay, Biographical Chronicle, 2.351.

38 Nashe, Haue with You to Saffron-Walden, 3.61; Stern, Gabriel Harvey, 120-1.

39 Wilhelm Lühr, Die drei Cambridger Spiele vom Parnass (1598-1603) in ihrer litterarischen Beziehungen, MA dissertation (University of Kiel, 1900), 31-2, 39-42; Schrickx, 'Portraiture of Gabriel Harvey'; Stern, Gabriel Harvey, 130; Leishman, ed., Parnassus Plays, 79-80. Schrickx identifies four speeches by Luxurio as quotations from Harvey, but the verbal correspondences that he highlights are very slight. The only unmistakeable quotation that Schrickx cites - a speech of Luxurio's in The First Part (1.1.417-28) that combines several phrases from Pierces Supererogation was noticed in the same year by Travis L. Summersgill, who drew the opposite conclusion, that 'ideas and phrases are distributed generally and with little relevance to character'. See 'Harvey, Nashe, and the Three Parnassus Plays', Philological Quarterly 31 (1952), 94-5.

40 For instance, Ingenioso greets him with 'Giue mee thy liquid hande, howe haste thou mantained thy nose in that redd sute of apparell ere since I lefte thee?' Luxurio retorts, 'thou enuiest that a mans nose shoulde be better apparelled than thy backe. Were thy disapointed selfe possest with such a spirit as inhabiteth my face, thou wouldest neuer goe fidlinge thy pamphletes from doore to dore like a blinde harper'; Ingenioso replies to this, 'Spirit calest thou it? It shoulde seeme by the fier thers a diuell' (1.1.387-400).

41 Nashe's depiction of Harvey's face emphasizes his swarthiness and how lined and careworn it is, but says nothing about its ruddiness: 'his complexion ... is of an adust swarth chollericke dye ... more channels \& creases he hath in his face than there be 
Fairie circles on Salsburie Plaine' (Haue with You to Saffron-Walden, 3.93). On meeting Harvey, Elizabeth I supposedly remarked on his Italianate complexion (Stern, Gabriel Harvey, 42).

42 Ibid., 185; Harvey, Letter-Book, 4, 14. At various points, Luxurio admits that 'all my debtes stande chaukt vpon the poste for liquor' (1.1.437), announces that he will drink himself blind in honour of Homer (5.2.1491-3), declares, 'I meane to drincke the worlde drye' (5.2.1517), etc.

43 For a survey of contemporary comment on ballads, much of it hostile, see Natascha Würzbach, The Rise of the English Street Ballad, 1550-1650, trans. Gayna Walls (Cambridge, New York, 1990), 253-84. To Harvey, ballads epitomize popular literature at its most worthless: in Pierces Supererogation he even has the lèse-majesté to find fault with the 'meeter' of James VI's Lepanto, written in the standard ballad form of 'eight and six'. See Sarah Knight, "It was not mine intent to prostitute my Muse in English": Academic Publication in Early Modern England', David Adams and Adrian Armstrong (eds), Print and Power in France and England, 1500-1800 (Aldershot, 2006), 42-3; Harvey, Pierces Supererogation, G4r. A large part of Harvey's annotated private library is extant: ballads seem not to have been one of his guilty pleasures. See 'Gabriel Harvey (1552/3-1631)', Catalogue of English Literary Manuscripts, 1450-1700, http://www.celm-ms.org.uk/authors/harveygabriel.html. For the Knight reference, I am grateful to Professor Stephen Knight (Melbourne), who is no relation.

44 See the descriptions of Elderton (d. 1592) collected by Hyder E. Rollins in 'William Elderton: Elizabethan Actor and Ballad-Writer', Studies in Philology 17 (1920), 199-245. For the stereotype, see William Webbe, A Discourse of English Poetrie (London, 1586; sтc: 25172), D1r-v; Nashe, The Anatomie of Absurditie, 1.23-4; Histrio-Mastix: Or, The Player Whipt (np, 1610; sтc: 13529), D4r; John Earle, Microcosmographie (London, 1628; sTC: 7439), F1v-F3r, etc. Würzbach attributes this to the socio-economic status of ballad writers (Rise of the English Street Ballad, 251).

45 Lühr, Die drei Cambridger Spiele vom Parnass, 31. Cf., for example, Josiah H. Penniman, The War of the Theatres (Boston, Halle, 1897), 154-5; Roscoe Addison Small, The Stage-Quarrel between Ben Jonson and the So-Called Poetasters (Breslau, 1899), 201-4; R. Warwick Bond (ed.), The Complete Works of John Lyly, 3 vols (Oxford, 1902), 3.101, 109-10.

46 Harvey, Foure Letters, D2r; Leishman (ed.), Parnassus Plays, 146n.

47 Leishman (ed.), Parnassus Plays, 207n; Harvey, Fovre Letters, E2v. In Pierces Supererogation, Harvey pours scorn on Lyly's 'euphuing of Similes' involving 'precious stones; \& straunge Foules, beastes, and fishes' (I4v).

48 See Cain (ed.), Poetaster, 19-23. 
49 Some scholars estimate this rise as a trebling, from around 150 in 1500 to between 400 and 500 by 1600. See Hugh Kearney, Scholars and Gentlemen: Universities and Society in Pre-Industrial Britain, 1500-1700 (London, 1970), 22. On the factors leading to this rise see Mark H. Curtis, 'The Alienated Intellectuals of Early Stuart England', Past and Present 23 (1962), 25-43; Lawrence Stone, 'The Educational Revolution in England, 1560-1640', Past and Present 28 (1964), 41-80. On the Elizabethan drive for an educated clergy, see Rosemary O'Day, Education and Society, 1500-1800: The Social Foundations of Education in Early Modern Britain (London; New York, 1982), 132-50. O’Day challenges Curtis, Stone, and Kearney's data, saying that this increase was merely the intensification of a pre-existing trend, but acknowledges that in the period 'the population [took] up the idea of a university education ... wholeheartedly' (81-8).

50 John Nichols's The Progresses and Public Processions of Queen Elizabeth I: A New Edition of the Early Modern Sources, Elizabeth Goldring et al. (eds), 4 vols (Oxford, 2014), 1.430, https://doi.org/10.1093/oseo/instance.00057589. For an exploration of what 'humanism' could mean to Harvey and his contemporaries, see Mike Pincombe, Elizabethan Humanism: Literature and Learning in the Later Sixteenth Century (Harlow, 2001), esp. 3-12. Pincombe emphasizes the belletristic aspects of humanism, laying great stress on a comment of Harvey's about 'superficial humanists' where, it seems to me, the opprobrium is taken wholly by 'superficial', while in context 'humanist' is identical to 'scholar'. For the passage in question, see Gabriel Harvey's Marginalia, ed. G.C. Moore Smith (Stratford-upon-Avon, 1913), 161. More relevant to Harvey's pragmatic and politically engaged humanism are Harold S. Wilson, 'The Humanism of Gabriel Harvey', James G. McManaway, Giles E. Dawson, and Edwin E. Willoughby (eds), Joseph Quincy Adams Memorial Studies (Washington D.C., 1948), 707-21; G.K. Hunter, John Lyly: The Humanist as Courtier (London, 1962), 13-35; Quentin Skinner, The Foundations of Modern Political Thought, 2 vols (Cambridge, 1978), 1.213-43, https://doi.org/10.1017/CBO9780511817878.

51 Ellinghausen, Labor and Writing, 49-52; G.W. Prothero (ed.), Select Statutes and Other Constitutional Documents Illustrative of the Reigns of Elizabeth and James I, 4th ed. (Oxford, London, 1913), 100-1.

52 Nashe, Pierce Penilesse, 1.157. For causes of the late-Elizabethan fluorescence of satire, see Richard Helgerson, Self-Crowned Laureates: Spenser, Jonson, Milton, and the Literary System (Berkeley, CA, 1983), 123; Lorna Hutson, Thomas Nashe in Context (Oxford, 1989), 198, 201.

53 The ballad Ellinghausen reproduces, 'Alas Poore Scholler, Whither Wilt Thou Goe', recounting the fate of an itinerant graduate 'fit to begg / in Hebrew, Greeke and 
Lattin', suggests the more acerbic take of a less educated constituency (Labor and Writing, 53).

54 See the grim picture painted in O'Day, Education and Society, 165-78, and David Cressy, 'A Drudgery of Schoolmasters: The Teaching Profession in Elizabethan and Stuart England', Wilfrid Prest (ed.), The Professions in Early Modern England (New York, 1987), 129-53.

55 True or false, Jonson's belief that Spenser 'died for lack of bread' was shared by several contemporaries. See The Cambridge Edition of the Works of Ben Jonson, David Bevington, Martin Butler, Ian Donaldson (gen. eds), 7 vols (Cambridge, 2012), 5.368; Ray Heffner, 'Did Spenser Die in Poverty?', Modern Language Notes 48 (1933), 2216, https://doi.org/10.2307/2912230. Although Heffner, in crediting these stories, sensibly sees Spenser's death in the specific context of the Nine Years' War, what is important to me is how Spenser's English contemporaries saw it.

56 H. Rushton Fairclough (ed.), Horace: Satires, Epistles and Ars Poetica (London, Cambridge, MA, 1929), 463n, https://doi.org/10.4159/dlcl.horace-satires.1926.

57 I quote McKerrow's comments in Nashe's Works, 5.65, 67. For a representative overview of comment, see David Perkins, 'Issues and Motivations in the HarveyNashe Quarrel', Philological Quarterly 39 (1960), 224-33; David C. McPherson, 'Aretino and the Harvey-Nashe Quarrel', PMLA 84 (1969), 1551-8, https://doi. org/10.2307/1261501; Kenneth Friedenreich, 'Nashe's Strange Newes and the Case for Professional Writers', Studies in Philology 71 (1974), 451-72; Stephen S. Hilliard, The Singularity of Thomas Nashe (Lincoln, NE, 1986), 169-220; Hutson, Thomas Nashe in Context, 197-214; Evelyn B. Tribble, Margins and Marginality: The Printed Page in Early Modern England (Charlottesville, VA, 1993), 101-29; Alexandra Halasz, The Marketplace of Print: Pamphlets and the Public Sphere in Early Modern England (Cambridge, 1997), 82-113, https://doi.org/10.1017/CBO9780511581892; Matthew Day, 'Hakluyt, Harvey, Nashe: The Material Text and Early Modern Nationalism', Studies in Philology 104 (2007), 281-305, https://doi.org/10.1353/sip.2007.0012.

58 Harvey, Marginalia, 151; Nashe, Pierce Penilesse, 1.157. 
